\title{
A NEW DISENFRANCHISED TYPE OF PERSON IN UKRAINIAN AND RUSSIAN SMALL PROSE OF THE LITERARY EMIGRATION OF 1919-1939
}

\section{Zhylenko Iryna}

Doctor of Philology, Associate Professor

ORCID ID 0000-0002-1982-710X

Sumy State University

Rymskyi-Korsakov St., 2, Sumy, 40007, Ukraine

ariadna.irina365@gmail.com

This article deals with the evolution of a disenfranchised type of person in the works of small prose of Ukrainian and Russian emigration writers in the period between 1919 and 1939.

In the stories by $V$. Leontovych and $V$. Fedorov the type of disenfranchised person is presented and formed under the conditions of the Bolshevik Regime. Thus, the characters of the works find themselves in situations of alienation or conflict with the Bolshevik authorities: among these we encounter Sarah Solomonivna, a professor, the nationalist Kost, Olexander Levenets (stories by V. Leontovych «Sarah Solomonivna», «Hynut Mriyi», «Vyhnantsi»), and the peasant Varenyk (stories by V. Fedorov «Sud Varenyka»). These disenfranchised individuals have no place in the new society.

The stories show how these individuals perceive hostility of the new order, the last one catching them all up gradually, and how each of these characters is being subjected to tests and trials by the new government. The attitude towards the protagonists from their neighbours and colleagues changes, giving place to arising suspicion and distrust.

The main characteristics of the new type of disenfranchised person of the 20-40s are alienation from both the politics of the new government and from the native environment, accompanied by a deep mental fatigue caused by the painful loss of the motherland, the last one developing into existential loneliness.

Keywords: small prose of emigration writers of the interwar XX century, Volodymyr Leontovych, Vasyl Fedorov, type of a new disenfranchised person.

\section{НОВА «ЗАЙВА» ЛЮДИНА В УКРАЇНСЬКІЙ І РОСІЙСЬКІЙ МАЛІЙ ПРОЗІ ЛІТЕРАТУРНОЇ ЕМІГРАЦІї 1919-1939 pp.}

\author{
Жиленко Ірнина \\ Доктор філологічних наук, доцент \\ ORCID ID 0000-0002-1982-710X \\ Сумський державний університет \\ вул. Римського-Корсакова, 2, м. Суми, 40007, Україна \\ ariadna.irina365@gmail.com
}

Розглянуто еволюичію типу «зайвої» людини у творах малої прози украӥнських $i$ російських письменників літературної еміграчиї 1919-1939 рр.

Зазначено, щзо в оповіданнях В. Леонтовича $i$ В. Федорова представлений тип «зайвої» людини, щуо сформувався в умовах більшовицького ладу. Герої творів - Сара Соломонівна, професор, народовець Кость, Олександр Левенець (оповідання В. Леонтовича «Сара Соломонівна», «Гинуть мрії», «Вигнанці»), селянин Вареник (оповідання В. Федорова «Суд Вареника») - усі вони знаходяться в ситуаціі відчуження до більшовиџької влади. Цим «зайвим» людям немає місия у новому суспільстві.

(C) Zhylenko I., 2020 
Відзначено, щзо вони відчувають ворожість з боку нового ладу, яка наздоганяє yсіх їх поступово, $і$ кожен із персонажів оповідань украӥнського й російського письменників проходить своєрідні випробування новою владою. Змінюється ставлення до героїв творів $і$ з боку сусідів та колег, з'являться підозра, недовіра до них.

Визначено головні риси, притаманні новій «зайвій» людині 20-40-х рр.: відчуження від політики нової влади, від рідного середовища, глибока душевна втоми від втрати вітчизни, щзо переростає в екзистенціальну самотність.

Ключові слова: еміграційна мала проза міжвоєнного двадиятиліття, Володимир Леонтович, Василь Федоров, тип нової «зайвої» людини.

Central problem. At each stage of the historical development, there were characters with tragic fates, alienated from society by their own and collective norms and principles of existence. The type of disenfranchised individuals emerged due to I. Turhenev («Shchodennyk Zayvoyi Ludyny») and found feedback in numerous works of the world literature remaining a subject of interest for literary critics. This «crisis type» (D. Fedorov) differed from all of the previous ones at various stages of literature development. Russian critics (V. Belinsky, M. Dobroliubov, M. Chernyshevsky, and M. Saltykov-Shchedrin), researchers of the Soviet era (V. Vorovsky, G. Bursov, G. Bely, and G. Makohonenko) contributed widely to this research. Y. Mann pointed out the main features of a superfluous person: «alienation from official Russia, from the native environment, a sense of intellectual and moral superiority, accompanied at the same time by mental fatigue, deep skepticism, disorder between word and deed» («відчуження від офіиійної Росії, від рідного середовища, почуття інтелектуальної й моральної переваги над нею, водночас душевна втома, глибокий скептицизм, розлад між словом і ділом») [Cit. for: 4, p. 204]

Ukrainian researchers add further inherent traits of a disenfranchised person: «alienation from the environment, intellectual and moral superiority over the inert surrounding, which did not take notice of the individual, squeezing him onto the periphery of its existence, feeling deep skepticism, typical for that time» («відчуження від довкілля, інтелектуальна й моральна зверхність над інертним оточенням, котре його не сприймало, витискаючи на периферію свого існування, переживання глибокого скепсису, притаманного тогочасному поколінню») [5, p. 379].

Modern literary critics such as A. Khazova, N. Popovych, D. Fedorov, O. Danylov, E. Nikolsky, and N. Fedoseenko, among others, actively study the disenfranchised type of person as an eternal, constantly present type, concept, and image, embedded into the context of contemporary works of Russian and Foreign literature. V. Fedorov underlines the merit of the Russian prose of the 1920s., «based on the classical tradition, [...] managed to develop a universal literary concept of the Soviet disenfranchised person, who would be defined in a more detailed way, vary, and will be filled with new content» («спираючись на класичну традицію, змогла виробити загальнолітературну концепцію радянськоі «зайвої» людини, котра буде уточнюватися, варіюватися, наповнюватися новим змістом») [10, p. 208]. Since the characteristics are varied and multi-layered, researchers claim the definition of the type of a disenfranchised person is quite ambiguous. E. Nikolsky rightly distinguishes the image of a disenfranchised type of person went beyond the works of art and became an independent cultural phenomenon. The disenfranchised individual is a single character who was not only a figment of the writer's imagination but became «a painful phenomenon in the life of the society caused by the crisis of the entire social system» («хворобливим явищем у житті суспільства, викликаного кризою усієі соиіальної системи») [6].

Comparative literature also studies the features of the image of disenfranchised individuals. Thus, O. Vechirko explores the concept of a disenfranchised character in works of English and Russian literature of the XIX century [1] while E. Nikolsky and D. Valchak investigate this type in Russian and Polish literature [7]. However, we did not come across 
any work researching the issues described above in either Ukrainian or Russian literature, which is where the relevance of the present work lies.

The purpose of the present work is to reveal and underline the typical characteristics of a «superfluous» person in Ukrainian and Russian emigration literature of 1919-1939 on the examples of works by Volodymyr Leontovych and Vasyl Fedorov.

Results of the research. When speaking about the literature of the twenty-year interwar period of the 20th century, we would have to put "superfluous people" into the quotation marks, given this artistic type arose and is too distant from the environment when compared to the last century. However, we still use this term since it is the closest to the literary type of the mentioned characters, who were against Bolshevik Regime and felt alien to the new government.

The new type of disenfranchised personality is presented in the stories by A. Chekmanovsky («Kolhoz imeni Lenina»), M. Dykanko («Didova revoljuziya»), I. Savin («Pianaya ispoved») and others [2, p. 100-120]. N. Fedoseyenko rightly points out that: «... we will consider the protagonist the typical character of the «superfluous person», genetically related to the romantic tradition». Some features of such a character can also be traced in realistic works of the emigration prose: «the hero's confidence in himself is destroyed by the will of fate, unsuitable for the hero», «the perception of his «superfluity», based on the feeling of being alien towards others and everything around him» («...будемо вважати типологічним характером «зайвої людини» героя, генетично пов'язаного із романтичною традицією». Деякі риси такого персонажа віддалено можна прослідкувати й у реалістичних творах еміграційної прози: «упевненість героя у собі руйнується волею неприхильної для героя долі», «сприйняття своєї «зайвості» героєм», яка трималася на чужості іншим і всьому оточенню») [11, p. 125, 127]. This is how the characters are portrayed in the works of the Ukrainian writer V. Leontovych (1866, Poltava province - 1933, Prague), and the author V. Fedorov (1895, Kherson 1959, Prague) who wrote in Russian.

The main character of V. Fedorov's story «Sud Varenyka» is a typical Ukrainian. His house stands alone, on the Dnipro's bank. With the arrival of Bolsheviks, the life of the hero was neatly divided into two parts - the one before their arrival and another one afterwards. Before the Bolsheviks came to power, Varenyk was a hard-working farmer, but became a kulak afterwards, after the incident with a commission consisting exclusively out of Slobodyan people: «they discovered the last bag of flour in the canopies with hardworking zeal which could have been compared to that of mice» («струдолюбивым рвением мымей откопала в сениах последний мешок муки») [9, p. 183]. The author compares Varenyk to Diogenes, since he would sit on a barrel near the shore, and his appearance reminds of the ancient philosopher: «His bare feet would hang down the same way as those of Diogenes, and even his gray eyebrows reminded of Diogenes» («ПI диогеновски свисали вниз его босые ноги, и седые брови лохматились подиогеновски») [9, p. 181].

Varenyk could not get rid of various obsessive thoughts («strange thoughts»). Throughout the story V. Fedorov emphasizes that everything «seemed ridiculous to him»: why have they taken «his own property: a bag of flour earned by the callosities of his hands...», why the owners even took away rotten potatoes, and why it had to be the former barchuk from among the students expelled high school. The hero is even afraid to die the new way, without a bishop. The present life for Varenyk is similar to a soldier's mess, where everything is mixed in one - «and the dirt, and all the dirty tricks». The hero perceives his uselessness: «...Imagine, now I feel as if I were superfluous... And what is with their lives?» Another time the author includes these thoughts in an internal monologue, in which the character tries to understand whether he is a «superfluous person» at present...» («...Пущай я теперь вроде как лишний... А им что за жизнь?». Іншим разом автор включаєці думки у внутрішній монолог, де герой намагаєтьсязрозуміти, чи й справді «лишний он человек по нынешним временам...») [9, p. 187, 191]. 
Varenyk even turned out to be an unwanted guest in his own daughter's house as he came to congratulate her on the birth of Marx, his grandson, though the ungodly name depressed him altogether. Not only the behavior, but also the face of his daughter seems to him «alien and over-painted». For him, the passers-by of Dniepropetrovsk are «...people [who are] superfluous and unfamiliar to him», the guests at christening parties are «parasites» in his eyes, and the glance of the son-in-law is unbearable for Varenyk», «he face he came to hate, as the face of the devil» («лицо, ненавистное ему, как лицо дьявола») [9, p. 194-201].

The heroes of the works by V. Leontovych seem to be disenfranchised, too: the commissioner Sarah Solomonivna from the story with the same title, and the 65-year-old professor, nationalist from the old generation Kost («Hynut Mrii») and the county marshal (the leader of the nobility in pre-revolutionary Russia), Olexander Levenets («Vyhnantsi»). The hostility of the new system catches up with all of them gradually, and each of the characters gets tested by the new government. One observes the changing attitude on the part of neighbors and colleagues, as suspicion and distrust arise.

Internal monologues consisting of numerous rhetorical questions make up a significant part in the works. Difficult obsessive thoughts torment the protagonist of the story «Hynut Mrii»: «Where am I going? What will happen? What will I do? Is everything that takes place now, the only sense of the whole life, and is it at all human, all that is being done currently? ... And what good can happen between all these people? ... He remembers the «hostile glance of the peasant», and realizes he must flee, but does not know where: «In the city where the Bolsheviks rule - away from his neighbours, from his countrymen to the Bolsheviks?» («Куди я їду? На який кінець? Що робитиму? I невже все, що діється, єдиний наслідок усього життя, і невже иче людське - те, щчо робиться?...І щуо може утворитися доброго середичх людей?..». Йому пригадується «ворожий погляд селянина», тому герой розуміє, шчо треба тікати, але не знає, куди: «У город, де панують большевики - од своїх сусід, од своїх земляків до большевиків?») [3, p. 204].

Also the life of Sarah Solomonivna becomes difficult with the communists' appearance. The same way as Aaron Nusimovych, Sarah does not want to adapt to changes, but desires to eat her bread, her meals, in an honest way: «I earned it, therefore it is mine, and if it is mine, then no damn person can take it away from me, and if they give it to you today for being a communist - it means today they want communists and therefore give it, - but if tomorrow they will change their mind, they would even take away what they have given you today... In that case I don't want it...» («Заробила, так моє, а як моє, так щзоб ніякий чорт забирати його в мене не важився, а як дають за те, щзо ти сьогодні комуністий, сьогодні схотять - дадуть, завтра не схотять - $i$ те, щзо дали, заберуть... то хай воно сказиться...») [3, p. 310]. Feeling herself superfluous, as if her life were of no meaning or would make no difference, the woman finds courage to flee abroad to her daughters by using tricks to obtain permission to leave the Ukraine. She is sad to leave Kyiv, dismal to remember the past. But two years later, when she finds out about hunger and fear in the Ukraine, and the situation was getting worse and worse, she thought, «I am not happy here, but still, thank God, I'm not there» («Тут мені зле, та дякувати Богові, щзо таки я не там») [3, p. 314].

Levenets turned out to be a disenfranchised citizen, too. His life changed drastically after the arrival of the Bolsheviks. He was respected by all, rich and poor. Since the marshal had worked in various public services for twenty-five years, he was certain to have «deserved the respect of people», which proves the autobiographical basis of the author's work who obtained a law degree and was engaged in agricultural and cultural activities before the revolution and participated in the work of local self-government. Moreover, he was a magistrate and influenced decisions of economic provincial regions by solving various issues of Poltava region for about a quarter of a century [8, p. 35-37].

The hero of the story by V. Leontovich gradually finds himself alienated. During their second invasion, the Bolsheviks arrested Levents, and villagers from the nearby villages came to ask for him and, thus, he was released. But the hatred towards the new government, 
which burned, plundered, killed, and abused of people, kept growing inside him with every day. Levenets was struck by grief, very similar to Varenyk from the story by Fedorov. He saw that the new government «had no sense and was wild». Olexander Ivanovych was seized by horror which «troubled his soul, darkened his thoughts» («жах скаламучував думу, тьмарив думки») [3, p. 294]. Besides, he was disturbed by lynching of the community over the peasants who denounced the Bolsheviks. Prokip Hryhorovych tried to explain everything («Do we really have to endure it, lower our heads till our hands will be tied? This is how we save the best we can: 〈...> we destroy our own communists» («Невже ж нам оцю напасть так і терпіти, невже хилити голову, поки скрутять? Ось і рятуємо, як уміємо: <..> наших комуністів $і$ нищимо») [3, p. 298]), but sad thoughts and despair did not abandon Levents.

Alexander Ivanovich, who subsequently was forced into exile, as well as some other people, about whom the hero came to know later from the magazine, turned out to be «superfluous»: «In the N-district in Poltava Bolsheviks surrounded and broke the so-called Pugach' «gang», which has been destroying Soviet institutions everywhere in Poltava and has been killing communists and Soviet officials for several years...» («В Н-ському повіті на Полтавщині большевики оточили та розбили так звану «банду» Пугача, яка протягом кількох років розбивала скрізь на Полтавщині радянські установи, забивала комуністів та радянських урядовців...») [3, p. 302]. The disenfranchised person tried to at least hurt the hated power, similar to Anarch, the character from «Povist pro Sanatoriynu Zonu» by M. Khvyliovyi who remarked: «Earlier, in other centuries, there were superfluous people, but now these extra ones are not only superfluous, but also became harmful. $<\ldots>$ We are the last of the Mohicans, the last phalanx of superfluous people» («Раніш, в інші століття, були зайві люди, а тепер иүі зайві не тільки зайві, але й шкідлиі <..> Ми - останні з могікан, остання фаланга зайвих людей») [12, p. 512].

Varenyk reminds of «the last of the Mohicans» as he arranged a lynching for his son-inlaw who had a strong desire to serve the Soviet power with all his might. As he could not endure further tortures, he tricked Stephan into the barn, with a promise to rewrite his property on his name, and said pulling the trigger: «I sentence you to death» («K расстрелу я тебя присудил») [9, р. 205].

The characters of the works by Leontovych and Fedorov are the personification of the spirit of their time. The opinion on behalf of the disenfranchised person of the Bolshevik era is expressed by the professor of Leontovych's story «Hynut Mrii»: "What is the future of such people? How can one live on with an empty heart, without love, love no one, live without faith and without a hope!..» («Яка будуччина такого народу? Як можна жити далі з порожнім серием, без любови, бо любити нікого, без віри й надї̈..») [3, p. 205].

Conclusions. Thus, in the emigration literature there is a type of a new «superfluent» person formed under the conditions of Bolshevism. Such a person presents the following inherent characteristics: alienation from both, politics of the new government as well as from his native environment, a feeling of deep mental fatigue from the loss of his homeland, which develops into existential loneliness. The «superfluent» people in the Ukrainian and Russian literature of the interwar period are the best, the brightest people of their time, who are suffering and are rooting for the fate of the state. They are usually alien to everyone: villagers who do not understand and denounce them to the Bolshevik authorities, frequently they are not even needed by their families. They especially feel alienated from a new power which uses inhumane methods on them. Usually, the new «superfluent» person cannot or does not want to be tested by the Bolshevik authorities, which he/she hates, therefore the individual chooses one of the following ways: or emigration / armed struggle, as in the works of small prose by V. Leontovych and V. Fedorov analyzed, or suicide as in «Beetle» by Teffi, «Black Swans» by G. Hazdanov, and others works still awaiting research. 


\section{СПИСОК ВИКОРИСТАНИХ ДЖЕРЕЛ}

1. Вечірко О. Л. Художня концепція світу і людини в англійській та російській літературі XIX століття (на матеріалі поеми Дж. Г. Байрона «Паломництво Чайльда Гарольда» та роману О. С. Пушкіна «Свгеній Онєгін») / О. Л. Вечірко // Науковий вісник Міжнародного гуманітарного університету. Сер.: Філологія. 2018. - № 37. - том 1. - С. 150-152.

2. Жиленко І. Р. Мала проза української й російської літературної еміграції 19191939 pр.: проблемно-тематична та жанрово-стильова типологія : дис... докт. філолог. наук: 10.01.05. / Ірина Жиленко - К., 2019. - 465 с. - Режим доступу : http://shron1.chtyvo.org.ua/Zhylenko_Iryna_Rudolfivna/Mala_proza_ukrainskoi_i_rosii skoi_literaturnoi_emihratsii_19191939_rr_problemno-tematychna_ta_zhanro.pdf

3. Леонтович В. М. Зібрання творів. В 4 т. Т. 2. / В. М. Леонтович - К. : Сфера, 2004. $-356 \mathrm{c}$.

4. Литературный энциклопедический словарь / Под общ. ред. В.М.Кожевникова, П. А. Николаева. - М. : Сов. энциклопедия, 1987. - 752 с.

5. Літературознавча енциклопедія : У двох томах. Т. 1 / Авт.-уклад. Ю. І. Ковалів. К : ВЦ «Академія», 2007. - 608 с.

6. Никольский Е. В, Вальчак Д. Тип «лишнего человека» в русской и польской литературе («zbędny człowiek» против «bohater werterowski»). // Либри Магистри. - 2019. - № 3 (9). - С. 93-123.

7. Никольский Е. В. Образ «лишнего человека» в контексте проблематики романа Орхана Памука «Снег» // Studia Humanitatis. - 2016. - № 3. - Режим доступу : http://st-hum.ru/sites/st-hum.ru/files/pdf/nikolsky_12.pdf

8. Окрилений Україною: До 150-річчя від дня народження В. Леонтовича (18661933) // Дати і події, 2016, друге півріччя: календар знаменних дат №2 (8). / Національна парламентська бібліотека України. - К., 2016. - С. 35-40.

9. Федоров В. Г. Канареечное счастье / Сост., предисл., примеч. В. П. Нечаева. - М. : Моск. рабочий, 1990. - 479 с.

10. Федоров Д. В. «Лишний человек» как вечный тип русской литературы / Д. В. Федоров // Научные труды кафедры русской литературы БГУ. Вып. І. Минск : РИВШ, 2002. - С. 199-211.

11. Федосеенко Н. Г. И. С. Тургенев: к вопросу о «лишнем человеке» // Вестник Санкт-Петербургского университета. - 2008. - Вып. 3. - Ч. ІІ. - С. 125-133.

12. Хвильовий М. Новели, оповідання «Повість про санаторійну зону». «Вальдшнепи». Роман. Поетичні твори. Памфлети. / М. Хвильовий. - К. : Наук. думка, 1995. - 816 с.

\section{REFERENCES}

1. Vechirko O. 1. Hudozhnya conceptsia svitu i ludyny v anhliyskiy ta rosiyskii literaturi XIX stolittia (na materiali poemy Dhz. G. Bairona «Palomnytstvo Chaild Harolda» ta romanu O. S. Pushkina «Evhenii Onehin») // Naukovyi Vinyk Mizhnarodnoho humanitarnoho universytetu. Ser. Filologia.2018, No.37. Tom 1. S. 150-152.

2. Zhylenko I.R. Mala proza ukrainskoi I rosiiskoi literaturnoi mihratsii 1919-1939 rr. problemno-tematychna ta zhanrovo-styliova typolohia: dys. doc. filol. nauk: 10.01.05. K. 2019. 465 s. $\quad$ Rezhym dostupu: http://shron1.chtyvo.org.ua/Zhylenko_Iryna_Rudolfivna/Mala_proza_ukrainskoi_i_rosii skoi_literaturnoi_emihratsii_19191939_rr_problemno-tematychna_ta_zhanro.pdf

3. Leontovych V. M. Zibrannya tvoriv v 4 t. T.2. K. Sfera, 2004. $356 \mathrm{~s}$.

4. Literaturnyi entsyclopedicheskiy slovar' / Pod obschey red. V. M. Kozhevnikova, P. A. Nikolaeva. M. Sov. Entsyclopedia, 1987. $752 \mathrm{~s}$.

5. Literaturoznavcha entsyclopedia u dvoh tomah. T. 1. Avtor-ukladach Y. I. Kovaliv. K. VTs «Akademia», 2007. $608 \mathrm{~s}$. 
6. Nikol'skiy V. E., Valchak D. Tip «lishnego» cheloveka v russkoy i polskoy literature («zbędnyczłowiek» против «bohaterwerterowski»). LibriMagistri, 2019. No.3 (9). S. 93-123.

7. Nikol'skiy V. E. Obraz «lishnego cheloveka» v contekste problematiki romana Orhana Pamuka «Sneg». StudiaHumanitatis, 2016. No.3. Rezhim dostupa: http://sthum.ru/sites/st-hum.ru/files/pdf/nikolsky_12.pdf

8. Okrylenyi Ukrainou. Do 150-richia vid dnia narodzhennia V. Leontovycha (18661933). Daty I podii 2016, druhe pivrichia, calendar znamennyh dat No 2 (8). Natsionalna parlamenska biblioteca Ukrainy. K., 2016. S. 35-40.

9. Fedorov V. G. Kanareechnoe schastie. M. Mosk. Rabochiy, 1990. 479 s.

10. Fedorov D.V. "Lishniy chelovek" kak vechnyi tip russkoy literatury. Nauchnye Trudy kafedry russkoy literatury BGU. Vyp. 1. Minsk. RIVSH, 2002. S. 199-211.

11. Fedoseenko N. G. I. S. Turgenev k voprosu o «lishnem cheloveke». Vesnik SPeterburgskogo universiteta. 2008. Vyp. 3. Ch.II. S.125-133

12. Hvylovyi M. Novely, opovidannia «Povist pro sanatoriynu zonu». «Valdshnepy». Roman. Poetychni tvory. Pamflety. K. Naukova Dumka, 1995. 816 s.

Received: 20 January, 2020 